\title{
I.UMIBUNG
}

\section{PENGARUH PENGGUNAAN UBI KAYU (Manihot utillisima) DALAM PEMBUATAN KWETIAU}

\author{
Mimi Harni ${ }^{1}$, Sri Kembaryanti Putri ${ }^{1}$, Gusmalini ${ }^{1}$ \\ ${ }^{1}$ Food Technology, Politeknik Pertanian Negeri Payakumbuh, \\ E-mail: mimiharni2009@gmail.com
}

\author{
Diterima : 06 Februari 2020 \\ Disetujui : 25 Agustus 2020 \\ Diterbitkan : 31 Agustus 2020
}

\begin{abstract}
ABSTRAK
Kwetiau adalah sejenis mi berwarna putih yang berasal dari Tionghoa namun dengan ukuran yang lebih lebar. Mi ini berbahan baku tepung beras, dengan karakteristik tidak kenyal seperti mi biasa dari terigu. Hal ini memungkinkan kita untuk mengganti pati dari tepung beras dengan pati dari ubi kayu. Walaupun demikian penggantian bahan ini diharapkan tidak mengurangi nilai gizi pada kwetiau yang dihasilkan. Oleh sebab itu penelitian ini bertujuan untuk melihat kandungan gizi yang terkandung pada kwetiau yang dihasilkan. Jumlah ubi kayu yang ditambahkan dimulai dari $0-40 \%$. Penambahan ubi kayu akan mengurangi penggunaan tepung beras. Pada penelitian ini ada 5 perlakuan dengan 1 kontrol tanpa penambahan ubi kayu dan ulangan 3. Rancangan yang digunakan adalah RAL dengan uji lanjutan Duncan's New Multiple Range Test (DNMRT) pada taraf nyata 5\%. Pengamatan yang dilakukan adalah uji proksimat. Hasil penelitian yang telah dilakukan dapat diambil kesimpulan bahwa perlakuan terbaik adalah (D) penambahan ubi kayu 30\%.
\end{abstract}

\section{Kata Kunci: ubi kayu, kwetiau}

\section{ABSTRACT}

Kwetiau is a kind of white noodles originating from Tionghoa but with a wider size. This noodle is made from rice flour, with characteristics not chewy like ordinary noodles from flour. This allows us to replace starch derived from rice flour with starch from cassava. Nevertheless the replacement of this material is expected not to reduce the nutritional value of the noodles produced. Therefore this study aims to look at the nutritional content contained in the noodles produced. The amount of cassava added starts from 0-40\%. The addition of cassava will reduce the use of rice flour. In this study there were 5 treatments with 1 control without the addition of cassava and replication 3. The design used was the RAL with Duncan's New Multiple Range Test (DNMRT) at a 5\% significance level. Observations made are proximate tests. The results of the research that have been done can be concluded that the best treatment is (D) the addition of $30 \%$ cassava.

Keywords: cassava, kwetiau, starch 


\section{PENDAHULUAN}

Program diversifikasi pangan dicanangkan oleh pemerintah bertujuan untuk pemanfaatan berbagai bahan pangan lokal daerah di seluruh Indonesia. Pada program ini, masyarakat diharapkan tidak terpaku pada satu jenis bahan pangan karena masih banyak bahan pangan lokal lainnya yang beranekaragam. Program ini juga diharapkan untuk menghindari ketergantungan pada salah satu bahan pangan contohnya beras dan terigu yang akhir-akhir ini kebutuhannya selalu mengalami peningkatan yang signifikan. Ketergantungan terhadap beras ini dapat dikurangi dengan tersedianya pangan beranekaragam yang bergantung pada kondisi sumber daya alam setempat sehingga dapat menghasilkan berbagai produk pangan. Salah satu produk yang masih berbahan baku beras adalah kwetiau.

Kwetiau adalah mi berwarna putih yang berasal dari Tionghoa namun dengan ukuran yang lebih lebar. Awalnya di Indonesia mi ini dikenal oleh masyarakat keturunan Tionghoa, kemudian berkembang ke berbagai kalangan. Mi ini berbahan baku tepung beras, sehingga dapat dimodifikasi dengan bahan lain yang mengandung pati dan diharapkan bahan yang ditambahkan tidak merubah warna dari produk tersebut yaitu putih. Bahan tersebut dapat berupa ubi kayu. Penambahan bahan tersebut dapat mengganti pati dari beras yang dikurangi. Menurut Murtiningrum, Bosawer, Istalaksana, Jading (2018) kadar pati dari umbi dari ubi kayu adalah $13,12 \%$ sampai 46,09\%

\section{METODE PENELITIAN}

\section{Bahan dan Alat}

Bahan-bahan dalam pembuatan kwetiau antara lain tepung beras, tapioka, garam, ubi kayu dan minyak. Bahan-bahan untuk analisa antara lain Alkohol 80\%, $\mathrm{HCl} 25 \%, \mathrm{NaOH}$ 45\%, Aquades, Petrolium benzene, Selenium, Asam sulfat pekat, $\mathrm{NaOH} 30 \%$, Asam borat 3\%, indicator Conway, Asam sulfat 0,025 N dan kertas saring.

Peralatan dalam penelitian meliputi alat yang digunakan dalam pembuatan kwetiau yaitu panci, timbangan, kompor, loyang, kukusan, sendok makan sedangkan peralatan untuk analisa adalah buret, cawan alumunium, oven, labu lemak, erlemeyer, pipet tetes, gelas piala, pengangas air, gelas ukur, pendingin balik, spatula, labu ukur, labu kedjal dan alat destilasi.

\section{Pelaksanaan penelitian}

Penelitian ini dimulai dengan pembuatan kwetiau dengan perlakuan penambahan ubi kayu melalui penurunan jumlah tepung beras yaitu 10-40\% dan sebagai kontrol kwetiau tanpa penambahan ubi kayu. Kwetiau yang dihasilkan selanjutnya dianalisa proksimatnya meliputi 


\section{I.UMBUNNG}

kadar air, kadar abu, kadar protein, kadar lemak dan kadar karbohidrat (Andarwulan, Kusnandar, Herawati, 2011).

\section{Rancangan}

Pada penelitian ini rancangan yang digunakan adalah Rancangan Acak Langkap (RAL) dengan 5 perlakuan dan tiga ulangan. Uji lanjutan menggunakan Duncan's New Multiple Range Test (DNMRT) pada taraf nyata 5\%. Adapun masing-masing perlakuan tersebut adalah sebagai berikut :
A : Tanpa pemakaian ubi kayu
B : Pemakaian ubi kayu $10 \%$
C : Pemakaian ubi kayu $20 \%$
D : Pemakaian ubi kayu $30 \%$
E : Pemakaian ubi kayu $40 \%$

\section{HASIL DAN PEMBAHASAN}

\section{Kadar Air}

Hasil penelitian dengan uji sidik ragam menunjukan bahwa perlakuan penambahan ubi kayu berpengaruh nyata pada kadar air kwetiau yang dihasilkan (taraf nyata 5\%). Hasil rata-rata kadar air dapat dilihat pada Tabel 1.

Tabel 1. Rata-rata kadar air kwetiau

\begin{tabular}{cccc}
\hline Perlakuan & Rata-rata kadar air \\
\hline E (Penambahan ubi kayu 40\%) & $59,41^{\text {a }}$ & & \\
C (Penambahan ubi kayu 20\%) & $58,74^{\text {b }}$ & & \\
B (Penambahan ubi kayu 10\%) & 58,09 & c & \\
D (Penambahan ubi kayu 30\%) & 57,89 & c & \\
A (Tanpa penambahan ubi kayu) & 54,13 & d \\
\hline
\end{tabular}

Angka-angka yang diikuti oleh huruf kecil yang sama pada baris yang sama dan huruf besar yang sama pada lajur yang sama berbeda tidak nyata menurut uji lanjutan DNMRT pada taraf nyata $5 \%$.

Berdasarkan Tabel 1 perlakuan penambahan ubi kayu 40\% (perlakuan D) memberikan nilai kadar air tertinggi dibanding perlakuan lainnya dan dengan penambahan ubi kayu kecenderungan kadar air menaik. Kadar air kwetiau dipengaruhi oleh penambahan air saat pembuatan adonan kwetiau, air yang berasal dari ubi kayu yang telah mengalami proses pengukusan dan uap air dari hasil pengukusan kwetiau. Jumlah air yang ditambahkan pada pembuatan adonan adalah sama. Tepung beras lebih higroskopis untuk menerima air, 
namun air yang ada adalah air bebas yang dapat menguap karena proses pemanasan. Pada ubi kayu yang terdapat adalah air terikat yang tidak dapat menguap lagi yang diperoleh saat pengukusan sehingga dengan penambahan ubi kadar air dapat meningkat. Menurut Winarno (2004) air bebas akan mengalami penguapan karena panas sedangkan air terikat akan tetap tertinggal pada bahan. Air bebas biasanya terdapat pada permukaan bahan.

\section{Kadar Abu}

Hasil uji sidik ragam dapat dilihat kadar abu kwetiau dengan penambahan ubi kayu saling berbeda tidak nyata antar perlakuannnya pada taraf nyata 5\%. Rata-rata kadar abu pada masing-masing perlakuan dapat diihat pada Tabel 2.

Tabel 2. Rata-rata kadar abu kwetiau

\begin{tabular}{lc}
\multicolumn{1}{c}{ Perlakuan } & Rata-rata kadar abu \\
\hline E (Penambahan ubi kayu 40\%) & $0,46^{\text {a }}$ \\
D (Penambahan ubi kayu 30\%) & $0,44^{\text {a }}$ \\
C (Penambahan ubi kayu 20\%) & $0,42^{\mathrm{a}}$ \\
A (Tanpa penambahan ubi kayu 10\%) & $0,29^{\mathrm{a}}$ \\
B (Penambahan ubi kayu 10\%) & $0,39^{\mathrm{a}}$ \\
\hline
\end{tabular}

Angka-angka yang diikuti oleh huruf kecil yang sama pada baris yang sama dan huruf besar yang sama pada lajur yang sama berbeda tidak nyata menurut uji lanjutan DNMRT pada taraf nyata $5 \%$.

Pada Tabel 2 terlihat kadar abu tertinggi diperoleh oleh perlakuan E (penambahan ubi kayu 40\%) dan menurun dengan berkurangnya penambahan ubi kayu, namun diantara perlakuan saling berbeda tidak nyata. Tinggi dan rendahnya kadar abu dipengaruhi oleh bahan baku produk yaitu beras dan ubi kayu karena abu berasal dari pembakaran bahan organik yang ada pada bahan. Kadar abu ubi kayu lebih tinggi dari dari kadar abu beras dengan demikian penambahan ubi kayu semakin tinggi akan meningkatkan kandungan abu dari kwetiau. Menurut FAO kadar abu ubi kayu antara 0,6-1,3\% (Aliou, 1998) sedangkan kadar abu beras adalah 0,19 (Budijanto dan Muaris, 2013).

\section{Kadar Protein}

Pada uji sidik ragam untuk analisa protein kwetiau dengan penambahan ubi kayu saling berbeda tidak nyata pada taraf nyata 5\%. Rata-rata kadar protein untuk beberapa perlakuan dapat dilihat pada Tabel 3. 


\section{L.UMBUNNG}

Tabel 3. Rata-rata kadar protein kwetiau

\begin{tabular}{lc}
\hline Perlakuan & Rata-rata kadar protein \\
\hline A (Tanpa penambahan ubi kayu) & $3,55^{\mathrm{a}}$ \\
B (Penambahan ubi kayu 10\%) & $2,35 \quad \mathrm{~b}$ \\
C (Penambahan ubi kayu 20\%) & $2,28 \quad \mathrm{~b}$ \\
D (Penambahan ubi kayu 30\%) & $2,13^{\mathrm{b}}$ \\
E (Penambahan ubi kayu 40\%) & $1,62 \quad 2^{\mathrm{c}}$ \\
\hline
\end{tabular}

Angka-angka yang diikuti oleh huruf kecil yang sama pada baris yang sama dan huruf besar yang sama pada lajur yang sama berbeda tidak nyata menurut uji lanjutan DNMRT pada taraf nyata $5 \%$.

Tabel 3 menunjukkan bahwa perlakuan A (tanpa penambahan ubi kayu) mempunyai kandungan protein tertinggi. Penambahan ubi kayu menyebabkan nilai protein semakin turun hal ini terjadi karena adanya penggantian bahan dari beras ke ubi kayu. Ubi kayu memang memiliki nilai protein lebih rendah dibanding beras, bahkan ubi kayu dikenal sebagai makanan yang miskin dengan protein. Hal ini dapat diatasi dengan cara menambahkan bahan lain yang mengandung protein pada kwetiau yang dihasilkan. Menurut Budijanto dan Muaris (2013) kandungan protein beras adalah 7,39\% sedangkan kadar protein ubi kayu adalah 1 gram dalam 100 gram singkong (Rukmana, 1997).

\section{Kadar Lemak}

Hasil uji sidik ragam untuk kadar lemak kwetiau saling berbeda nyata pada (taraf 5\%). Berikut ini rata-rata lemak kwetiau oleh panelis dapat dilihat pada Tabel 4 .

Tabel 4. Rata-rata kadar lemak kwetiau

\begin{tabular}{cc}
\hline Perlakuan & \multicolumn{1}{c}{ Rata-rata kadar lemak } \\
\hline D (Penambahan ubi kayu 30\%) & $2,63^{\mathrm{a}}$ \\
E (Penambahan ubi kayu 40\%) & $2,54^{\mathrm{a}}$ \\
B (Penambahan ubi kayu 10\%) & $2,47^{\mathrm{a}}$ \\
C (Penambahan ubi kayu 20\%) & $2,46^{\mathrm{a}}$ \\
A (Tanpa penambahan ubi kayu) & $2,14^{\mathrm{b}}$ \\
\hline
\end{tabular}

Angka-angka yang diikuti oleh huruf kecil yang sama pada baris yang sama dan huruf besar yang sama pada lajur yang sama berbeda tidak nyata menurut uji lanjutan DNMRT pada taraf nyata $5 \%$.

Rata-rata kadar lemak tertinggi pada Tabel 4 adalah perlakuan D (penambahan ubi kayu 30\%). Kadar lemak selain berasal dari bahan baku juga berasal dari penggunaan minyak saat pengukusan yaitu untuk pembaluran kwetiau agar tidak lengket sesamanya. Beras dan ubi kayu bukan merupakan bahan pangan yang mengandung lemak tinggi. Nilai kadar lemak ini kemungkinan dari penggunaan minyak selama pembuatan kwetiau karena 
terlihat perlakuan D yang mempunyai kadar lemak tertinggi. Kadar lemak ubi kayu varietas Darul Hidayah berkisar 1,21 $\pm 0,08 \%$, Adira 4 berkisar 0,19 $\pm 0,10 \%$, dan Malang 4 berkisar $0,13 \pm 0,04 \%$. Kadar lemak ubi kayu ini berbeda hal ini dipengaruhi oleh iklim, media tanam, kesuburan dan pemeliharaan tanah (Ariani, Estiasih, Martati, 2017). Menurut Budijanto dan Muaris (2013) kadar lemak beras adalah 0,9\%.

\section{Kadar Karbohidrat}

Pada penelitian yang telah dilakukan kadar karbohidrat saling berbeda tidak nyata pada taraf 5\%. Nilai rata-rata karbohirat untuk semua perlakuan dapat dilihat pada Tabel 5.

Tabel 5. Rata-rata kadar karbohidrat kwetiau

\begin{tabular}{ll}
\multicolumn{1}{c}{ Perlakuan } & \multicolumn{2}{c}{ Rata-rata kadar karbohidrat } \\
\hline A (Tanpa penambahan ubi kayu) & $40,55^{\mathrm{a}}$ \\
D (Penambahan ubi kayu 30\%) & $36,42^{\mathrm{b}}$ \\
B (Penambahan ubi kayu 10\%) & $36,38^{\mathrm{b}}$ \\
C (Penambahan ubi kayu 20\%) & $35,62 \quad 2^{\mathrm{c}}$ \\
E (Penambahan ubi kayu 40\%) & $33,61 \quad$ d \\
\hline
\end{tabular}

Angka-angka yang diikuti oleh huruf kecil yang sama pada baris yang sama dan huruf besar yang sama pada lajur yang sama berbeda tidak nyata menurut uji lanjutan DNMRT pada taraf nyata $5 \%$.

Hasil Tabel 5 menunjukan bahwa perlakuan A (tanpa penambahan ubi kayu) memiliki nilai rata-rata karbohidrat tertinggi. Rata-rata terendah justru penambahan ubi kayu 40\%. Dari data di atas penambahan ubi kayu akan menurunkan nilai karbohidrat dari kwetiau. Nilai karbohirat beras memang lebih tinggi dari ubi kayu oleh sebab penuruanan penggunaan beras dengan ubi kayu akan menurunkan kandungan karbohidrat. Menurut Departemen Kesehatan RI (2001) kadar karbohidrat ubi kayu adalah 34,70\% sedangkan kadar karbohidrat beras yaitu 79,64\% (Budijanto dan Muaris, 2013).

\section{KESIMPULAN DAN SARAN}

\section{Kesimpulan}

Berdasarkan pada hasil penelitian yang telah dilakukan dapat diambil kesimpulan sesuai tujuan sebagai berikut :

1. Ada pengaruh penambahan ubi kayu dalam pembuatan kwetiau pada kadar air, kadar protein, kadar lemak dan kadar karbohidrat.

2. Perlakuan terbaik secara kimia namun dengan memperhatikan sifat fisik maka perlakuan yang dipilih adalah penambahan ubi kayu 30\% (D). 


\section{I.UMIBUNG}

\section{Saran}

Dari penelitian yang telah dilaksanakan disarankan penelitian lanjutan untuk menaikan nilai protein pada kwetiau yang sudah ditambahkan ubi kayu.

\section{REFERENSI}

Ariani, L.N, T. Estiasih, E. Martati. 2017. Karakteristik Sifat Fisiko Kimia Ubi Kayu Berbasis Kadar Sianida. Jurnal Teknologi Pertanian Vol. 18 No. 2. Hal 119-128. Didownload Tanggal 17 November 2019.

Andarwulan, Kusnandar, D. Herawati. 2011. Analisis Pangan. Dian Rakyat. Jakarta.

Aliou, D. 1998. Storage and processing of roots and tubers in the tropics. Dilihat 9 Februari 2016.

Budijanto, Muaris. 2013. Beras Analog Pangan Alternatif mirip Beras Non Padi. PT. Gramedia Pustaka Utama. Jakarta.

Departemen Kesehatan RI. 2011. Daftar Komposisi Gizi Makanan. Jakarta.

Murtiningrum, E.F. Bosawer, Istalaksana, A. Jading. 2018. Karakterisasi Umbi dan Pati Lima Kultivar Ubi Kayu (Manihot esculenta). https://www.researchgate.net. (Didownload Tanggal 18 November 2019).

Rukmana. 1997. Ubi kayu Budidaya dan Pasca Panen. Penerbit Kanisius. Yogyakarta.

Winarno, F.G. 2004. Kimia Pangan dan Gizi. PT. Gramedia Pustaka Utama. Jakarta. 